\title{
EFEKTIVITAS PENGGUNAAN BUSY BOOK TERHADAP KECERDASAN LOGIKA MATEMATIKA ANAK USIA DINI
}

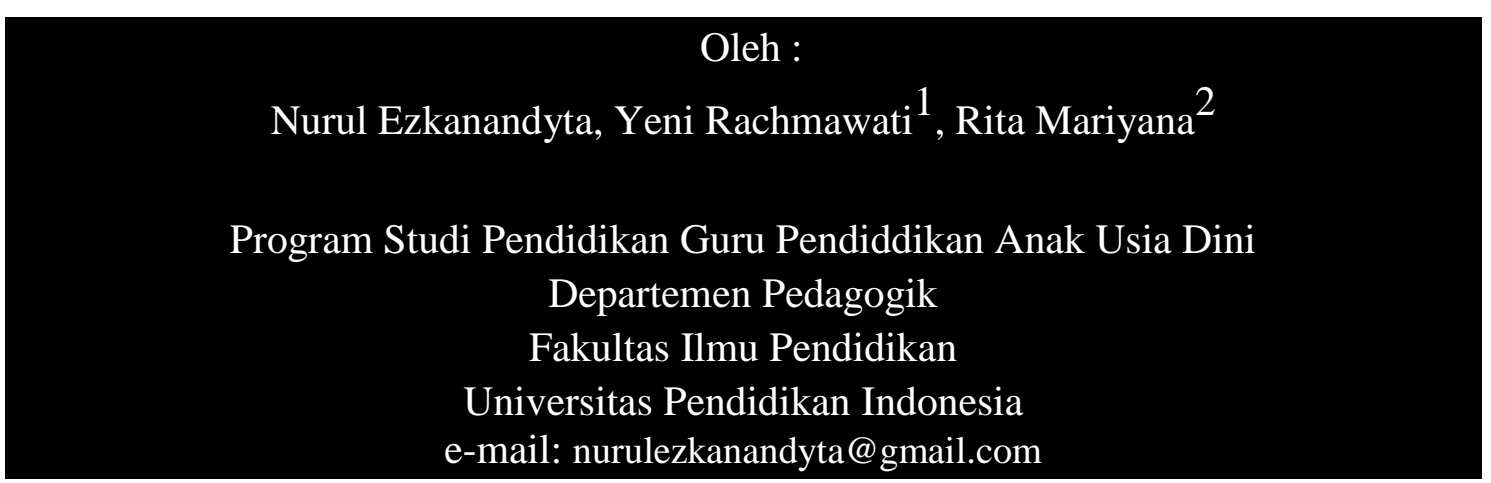

Abstrak: Anak usia dini adalah sosok individu yang sedang menjalani suatu proses perkembangan dengan pesat dan fundamental bagi kehidupan selanjutnya. Tugas-tugas perkembangan menjadi jalan untuk pemberian menstimulasi dan memberikan kegiatan atau aktivitas yang akan menghasilkan kemampuan dan keterampilan anak yang berguna bagi masa depannya dalam mencegah anak kesulitan berkomunikasi,. Kecerdasan logika matematika pada anak diharapkan terstimulasi dengan baik dengan harapan anak memiliki mental dan pemikiran cerdas, kreatif, dinamis, inovatif, mandiri, kritis, komunikatif, disiplin dan bertanggung jawab. mampu untuk menyelesaikan masalah, berpikir secara logis, serta terampil dalam mengolah angka. keberhasilan dalam menstimulasi kecerdasan logika matematika tergantung pada alat permainan edukatif yang digunakan. Tujuan dari penelitian ini adalah untuk mengetahui efektivitas penggunaan alat permainan edukatif busy book terhadap kecerdasan logika matematika anak usia dini. Metode penelitian yang digunakan adalah kuasi eksperimen dengan sampel penelitian yaitu kelompok B di TK Labschool UPI Bandung. Hasil penelitian diperoleh signifikansi sebesar $0,00<0,05$ yang menunjukkan terdapat perbedaan profil kecerdasan logika matematika anak usia dini yang signifikan setelah menerapkan treatment pada kelompok eksperimen. Dengan demikian terdapat efektivitas dalam penggunaan alat permainan edukatif busy book. Analisis yang digunakan untuk memperkuat penelitian ini menggunakan grafik, tabel dan hasil uji statisika. Diharapkan pada penelitian selanjutnya dapat inovasi dan alat permainan edukatif yang variatif serta memiliki landasan teori yang kuat dalam penelitian.

Kata Kunci: Kecerdasan Logika Matematika, Alat Permainan Edukatif busy book, efektivitas,

\footnotetext{
1 Penulis Penanggung Jawab 1

2 Penulis Penanggung Jawab 2
} 
Abstract: Early child is an individual whom in undergoing process of rapid and fundamental development to the next life. Development tasks become a way for stimulating and providing activities that will produce the abilities and skills of children that are useful for their future, in preventing children from communicate difficulties. Logic Mathematical intelligence in children is expected to be well stimulated aims children to have good mental and smart, creative, dynamic, innovative, independent, critical thinking, communicative, discipline and responsible, able to solve problems, think logically, and numbers skill. Well stimulated in logic mathematics intelligence depends on the educational toy. The purpose of this research is to determine the effectiveness of educational toy "busy book" toward logic mathematics intelligence in early childhood. The research method used was quasi-experiment in B groups as research samples in TK Labschool UPI Bandung. The results obtained significance of $0.00<0.05$ which indicates there are significant differences in logic mathematics intelligence profile of early childhood after applying treatment to the experiment group. Thus, there is effectiveness of using "busy book" educational toys. The analysis used to strengthen this study uses graphs, tables and statistical test results. It is hoped that in future research, there will be varied innovations in educational toys that have a strong theoretical research.

Keywords: Logic mathematics intelligence, Educational toys, busy book, Effective 


\section{PENDAHULUAN}

Pendidikan usia dini merupakan pondasi awal bagi pertumbuhan dan perkembangan dan salah satu penyelenggaraan pendidikan dalam memfasilitasi perkembangan fisik (koordinasi motorik halus dan kasar), kecerdasan (daya pikir, daya cipta, kecerdasan emosi, kecerdasan spiritual), sosio emosional (sikap dan perilaku serta beragama), bahasa dan komunikasi yang dapat berguna terhadap keberhasilan individu pada masa yang akan datang (Sujiono, 2009 hlm.6). NAEYC dalam Yuliani (2009, hlm. 6) menyatakan bahwa anak usia dini adalah sosok individu yang sedang menjalani suatu proses perkembangan dengan pesat dan fundamental bagi kehidupan selanjutnya. Pendidikan bagi anak usia dini adalah pemberian upaya untuk menstimulasi, membimbing, mengasuh, dan memberikan kegiatan pembelajaran yang akan menghasilkan kemampuan dan keterampilan anak yang berguna bagi masa depannya.

Menurut Piaget (dalam Salkind 2009, hlm. 313) perkembangan sebagai proses spontan dan kemampuan bawaan individu bersikap dinamis bukan statis. Interaksi antara sistem informasi internal individu dengan tuntutan lingkungan mendorong upaya untuk mencapai keseimbangan yang menjadi inti perkembangan. Banyak penelitian yang menunjukkan bahwa otak pada anak usia dini telah mencapai $80 \%$ dari otak orang dewasa (Suyadi, 2010, hlm. 267). Pada usia awal perkembangan anak sebaiknya diberikan stimulasi yang tepat untuk mendukung perkembangannya. Ciri khas perkembangan pada anak usia dini disebut periode kritis dari sudut pandang Bloom (dalam Salkind 2009, hlm. 57) yang menunjukkan bahwa waktu optimal untuk pelaksanaan intervensi agar individu bisa terbantu menghindari masalah-masalah perkembangan yang potensial adalah dalam 3 tahun pertama kehidupannya, yakni ketika laju perubahan berlangsung paling cepat dalam berbagai dimensinya. Periode kritis disebut sebagai tugas-tugas perkembangan (development tasks) yang diartikan sebagai periode yang dibatasi oleh waktu dan berkembang secara kontinyu.

Anak usia dini berada pada rentang usia sejak lahir sampai berusia 6 tahun sangat peka akan rangsangan (periode sensitif) yang diberikan oleh dan masa yang tepat untuk memberikan stimulasi dan pada usia golden age (Hainstock, 1999 hlm. 34) Stimulasi yang diberikan pada usia 0-6 tahun akan memberikan pengaruh yang besar pada anak terutama pada awal kehidupannya dan stimulasi tersebut dapat dijadikan sebagai pondasi agar potensi yang dimiliki oleh anak dapat berkembang secara optimal. Kesiapan (readiness) anak dan kematangan dalam menerima stimulasi 
harus siap secara biologis sebelum maju ke tahapan perkembangan berikutnya. Bruner (1996, hlm.33) menyatakan kesiapan terhadap pertumbuhan biologis dengan memasukkan perubahanperubahan fungsi kognitif, dari proses secara enaktif menuju pemrosesan informasi secara simbolik sehingga perlu diadaptasikan dengan tingkat perkembangan yang tengah dialami anak. Sejak lahir setiap anak sudah memiliki kecerdasan dan keunikan yang berbeda-beda antara anak yang satu dengan yang lainnya. Kecerdasan merupakan kemampuan untuk menyelesaikan masalah dan setiap anak memiliki cara berpikir yang berbeda dalam membangun pengalaman yang baru (Gardner dalam Sujiono 2009, hlm. 176).

Multiple Intelligence atau disebut sebagai kecerdasan jamak adalah perkembangan yang mutakhir dalam bidang intelegensi yang menjelaskan jalur yang digunakan manusia untuk menjadi cerdas (Lazear, 2000, hlm.7). Gardner (1993, hlm. 3-5) menyatakan setiap anak mempunyai kecerdasan namun tiap individu memiliki profil kecerdasannya masing-masing dan dapat berkembang dengan stimulasi dan kecerdasan yang dikembangkan dapat lebih dari satu kecerdasan, yakni yang terdiri atas kecerdasan linguistik, kecerdasan logika matematika, kecerdasan visual spasial, kecerdasan musikal, kecerdasan kinestetik, kecerdasan interpersonal dan kecerdasan intrapersonal. Lebih lanjut Gardner menambahkan dalam Reframed Mind (dalam Smith, 2002) terdapat kecerdasan naturalistik dan kecerdasan eksistensial.

Kecerdasan logika matematika pada anak usia dini (Suyanto 2003, hlm.6) menjadi hal penting untuk distimulasi khususnya 50\% dari potensi intelektual anak sudah terbentuk di usia 4 tahun dan mencapai $80 \%$ pada usia 8 tahun. Selanjutnya menurut Gardner
(1983) kecerdasan logika matematika merupakan kecerdasan yang diperlukan dan dapat membantu anak pada saat proses pendidikan dan karena setiap kegiatan sehari-hari berhubungan dengan angka atau berhitung dan berpikir. Kecerdasan logika matematika penting untuk di stimulasi karena kecerdasan logika matematika adalah kecerdasan yang menuntut anak untuk berpikir secara logis, dari sebuah pemikiran yang logis tersebut akan menghasilkan sebuah pemikiran atau gagasan yang dapat di terima olehorang lain. Kecerdasan logika matematika menurut Musfiroh (2004) berkaitan dengan kemampuan mengolah angka atau disebut kemahiran menggunakan logika. Anak yang memiliki kecerdasan logika matematika tertarik dalam memanipulasi hal disekitarnya, cenderung senang mencoba(trial-error) serta senang menduga, memiliki rasa ingin tahu. Potensi intelektual anak (dalam Nur, 2018) mulai terbentuk sejak usia 4 tahun dan anak dapat mengenali bentuk, ukuran dan benda berdasarkan pengalamannya

Peran penting kecerdasan logika matematika menurut Nur $(2018$, hlm. 4) bagi anak dalam kehidupan sehari-hari dalam kemampuan untuk menyelesaikan masalah, serta mencegah anak kesulitan berkomunikasi, menemukan pola yang berguna untuk melakukan kalkulasi hitungan dan berpikir secara abstrak membantu anak dalam mengembangkan kemampuan berpikir secara logis dan ilmiah. Uno \& Umar (2009, hlm. 11) mendefinisikan kecerdasan logika matematika adalah kemampuan dalam berfikir secara induktif dan deduktif, berfikir menurut aturan logika, memahami dan menganalisis pola angka-angka, serta memecahkan masalah dengan menggunakan kemampuan berfikir. Yus (2011, hlm. 71) menyatakan kecerdasan logika matematika adalah kemampuan untuk memahami dasar-dasar 
operasional yang berhubungan dengan angka dan prinsip-prinsip serta kepekaan melihat pola dan hubungan sebab akibat dan pengaruh. Dari pendapat para ahli di atas dapat disimpulkan kecerdasan logika matematika adalah kemampuan untuk memahami dasar-dasar operasional, berpikir logis untuk menganalisa kasus atau permasalahan dan melakukan perhitungan sistematis. Perkembangan kognitif menurut Rahma (2014) memiliki hubungan yang erat terhadap kecerdasan logika matematika sehingga stimulasi kecerdasan logika matematika dapat membantu perkembangan kognitif khususnya dalam memperoleh informasi, kapasitas berpikir, mengingat, mengklasifikasikan, penyelesaian masalah atau problem solving, dan reasoning.

Pada dasarnya setiap anak dianugerahi kecerdasan logika matematika (Lwin dalam Nur, 2018, hlm. 1) Pada pengaplikasiannya dalam kehidupan sehari-hari yaitu anak dapat dilatih meningkatkan pengertian pada bilangan, menemukan hubungan sebab akibat dan meningkatkan kemampuan berpikir logisnya Suyadi (2010, hlm 9192). Robin (dalam Simister 2007, hlm. 56) menjadikan bertanya logis adalah sebuah bagian dari kemampuan anak yang wajib ditumbuhkan secara terus menerus dikarenakan bertanya sebagai tanda keingintahuan adalah salah satu karakteristik paling permanen dan pasti dari pemikiran yang kuat. Keingintahuan menandakan semangat yang aktif, terbuka dan berorientasi pada pemecahan masalah dan merupakan elemen penting dari kreativitas, inovasi dan kemajuan anakanak. Sujiono (2010, hlm.58) Kecerdasan logika matematika melibatkan keterampilan mengolah angka dan atau kemahiran menggunakan logika dan akal sehat sehingga diharapkan terciptanya hubungan-hubungan yang kelak diharapkan anak memiliki mental dan pemikiran cerdas, kreatif, dinamis, inovatif, mandiri, kritis, komunikatif, disiplin dan bertanggung jawab.

Pada umumnya proses pembelajaran hanya terfokus pada tujuan akademis dan praktik pembelajaran yang sesuai dengan perkembangan anak belum sepenuhnya terimplementasikan karena masih terdapat anak yang belum mampu dalam membilang dengan menunjuk benda, anak kesulitan dalam mengurutkan lambang bilangan, anak juga masih bingung dalam menunjukkan kumpulan yang sama jumlahnya, yang tidak sama, dan lebih sedikit. Fiani (2012) menemukan guru masih belum memahami strategi dan metode yang tepat dalam mengembangkan kecerdasan logika matematika anak dikarenakan hanya terpaku pada perintah dan aktivitas monoton serta pembelajaran kurang bermakna bagi anak yang mengakibatkan anak kurang diberi kesempatan untuk mengembangkan kemampuan dan potensinya. Menurut Rozi (2012) kemampuan anak salah satunya dalam berhitung masih tergolong rendah dikarenakan media yang digunakan kurang menarik bagi anak. Pembelajaran yang dilaksanakan oleh guru dalam meningkatkan kecerdasan logika matematika belum mengarah pada tujuan yang diharapkan. Mufarizuddin (2017, hlm. 3) bahwa kecerdasan logika matematika sulit mengalami peningkatan dikarenakan pembelajaran yang dilakukan guru belum tepat dalam pengenalan angka pada anak. Lebih lanjut Susyanti (2013) menemukan rendahnya kecerdasan logika matematika anak yang ditandai kurangnya kemampuan anak dalam membilang dan berhitung. Anak menunjukkan keterlambatan dalam perkembangan logika matematika khususnya pada aktivitas berhitung dikarenakan guru kesulitan menyesuaikan metode dengan karakteristik anak usia dini Zubaidah 
(2012). Proses pembelajaran menurut Wulani (2011) guru dalam menstimulasi kecerdasan logika matematika hanya melalui kegiatan individu paper-based dan metode ceramah sehingga tujuan pembelajaran dalam menstimulasi kecerdasan logika matematika sulit dicapai. Kondisi yang ditemukan oleh Silmi (2015) kemampuan anak terhadap konsep bilangan masih rendah, kesulitan menghitung jumlah benda dari gambar dikarenakan kurangnya kegiatan pengenalan konsep bilangan dan media yang digunakan untuk mengenal polapola dan simbol-simbol dalam mengembangkan kecerdasan logika matematika anak masih belum digunakan. Pembelajaran di Taman Kanak-Kanak menggunakan soal hitungan seperti tingkat sekolah dasar dalam menilai dan mengukur pencapaian anak dalam perkembangan kecerdasan logika matematika tanpa mengembangkan logika berpikir anak sudah sering dilakukan (Indriani, 2016 hlm. 172). Anak memiliki beberapa masalah yang ditemukan yaitu anak belum mampu menemukan bermacammacam alternatif pemecahan masalah, kemampuan berpikir logis, pengetahuan konsep ruang dan waktu, anak masih memerlukan bimbingan dalam memilah memilih, mengelompokkan benda dengan berbagai cara, memasangkan benda sesuai dengan pasangannya (dalam Nur, 2018). Selain itu ditemukan pula permasalahan masih minimnya pengetahuan guru pentingnya alat permainan edukatif yang dapat menstimulasi kecerdasan logika matematika anak, yang umumnya anak diajarkan dengan cara konvensional dan lebih berpusat pada guru (teacher centered) yang memungkinkan guru jauh lebih aktif namun anak tidak dapat mengeksplor pengetahuannya dengan cara yang menyenangkan. Diketahui bahwa kecerdasan logika matematika pada anak usia dini memiliki dampak yang besar pada proses perkembangan individu di masa depan. Dalam Nur
(2018, hlm. 4) anak yang kurang distimulasi dalam perkembangan kecerdasan logika matematika akan memiliki masalah dalam berkomunikasi serta asosiasi visual dan motorik yang berarti anak mudah mengingat angka namun tidak mengerti maksud yang disampaikan mengakibatkan kesulitan dalam pembelajaran. Lwin (dalam Agustin 2008, hlm 77) Pengembangan kecerdasan logika matematika yang ditinjau untuk dimensi perkembangan karier masa depan anak yaitu individu yang tidak memiliki kepekaan terhadap bilangan akan sulit untuk berpikir secara realistis yang berdampak pada saat individu membuat keputusan. Perlunya upaya guru dalam menstimulasi serta menggunakan alat permainan yang dapat membantu proses selama anak berkembang menuju hal yang diharapkan.

Terdapat beberapa penelitian terdahulu mengenai kecerdasan logika matematika dengan menggunakan berbagai metode dan media. Beberapa metode yang pernah digunakan terhadap kecerdasan logika matematika anak usia dini diantaranya yaitu pendekatan multisensori (Fiani, 2012), menggunakan metode studi eksplorasi pada pembelajaran terpadu model webbed berbasis kecerdasan jamak (Caturiyati, 2007), menggunakan hubungan antara tingkat pendidikan ibu dengan kecerdasan logika matematika anak usia dini (Hidayati (2015, hlm. 139-156), menggunakan Term, Fact, Principle (TFP) pada sentra balok (Zukhairina, 2018). Terdapat beragam media yang digunakan pada anak usia dini terhadap kecerdasan logika matematika diantaranya sudah dikembangkan dan diujicoba yaitu media papan telur (Rozi, 2012), menggunakan kartu angka (Mufarizuddin, 2017, hlm. 3), jarimagic oleh Susyanti (2013), alat permainan Monopoli Raksasa Edukatif (MONRAKED) yang dikembangkan oleh Fadlillah (2018 hlm. 9-23), 
permainan ular tangga (Zubaidah, 2012), permainan tradisional congklak (Wulani, 2011), flashcard (Silmi, 2015), Kolak (Kolase angka)Suryani (2018, hlm. 253-258). Adapun Salah satu penelitian yang menggunakan alat permainan edukatif busy book yang dilakukan oleh Annisa (2016) terhadap kemampuan visual-spasial yang ditandai oleh peningkatan pemahaman kiri-kanan dan pemahaman perspektif pada anak usia dini dilihat dari hasil perhitungan menunjukkan hasil uji $t$ independen adalah 0,000, yang artinya $0,000<0,05$, maka Ho ditolak dan Ha diterima yang berarti terdapat pengaruh Alat Permainan Edukatif (APE) busy book terhadap kecerdasan visual-spasial anak. Adapun penelitian ini akan lebih fokus pada kecerdasan logika matematika.

Meskipun penelitian mengenai kecerdasan logika matematika sudah banyak diteliti tetapi penelitian dengan menggunakan alat permainan edukatif busy book masih belum banyak dilakukan. Oleh karena itu peneliti tertarik melakukan penelitian menggunakan alat permainan edukatif. Berdasarkan permasalahan diatas, peneliti memfokuskan kajian penelitian yaitu Efektivitas Penggunaan Alat Permainan Edukatif Busy Book Terhadap Kecerdasan Logika Matematika Anak Usia Dini.

\section{METODE PENELITIAN}

Penelitian ini merupakan penelitian Quasi Eksperimental Design dengan one Experimental group pretest dan posttest serta one Control group pretest dan posttest menggunakan analisis data kuantitatif. Penelitian ini juga menggunakan sub desain Nonequivalent Control Group design dengan tujuan bahwa kelompok eksperimen maupun kelompok kontrol tidak dipilih secara random. Sampel yang akan digunakan yaitu kelas B TK Labschool UPI Bandung tahun ajaran 2019-2020.
Dikarenakan kelas B yang ada pada sekolah tersebut hanya terdiri dari dua kelas, peneliti kemudian memutuskan untuk memilih Kelas Gamelan dan Kelas Kecapi sebagai sampel penelitian. Penelitian eksperimen yang dilakukan bertujuan untuk menguji hubungan sebab akibat apakah suatu variabel (variabel bebas) menyebabkan hasil pada variabel (terikat) Kerlinger (dalam Setyosari (2012, hlm. 42). Penelitian eksperimen ini digunakan untuk mengukur hubungan, pengaruh, atau perbedaan variabel-variabel sesuai dengan masalah dan tujuan penelitian

Metode Kuantitatif digunakan peneliti pada penelitian ini.

\section{HASIL DAN PEMBAHASAN}

Analisis Profil (Skor Pre-test)

Kecerdasan Logika Matematika Anak

Usia Dini

a) Uji Normalitas Data Pre-Test Hasil uji normalitas (pre-test) kelas eksperimen dan kelas kontrol Tests of Normality

\begin{tabular}{|r|r|r|}
\hline \multicolumn{3}{|c|}{ Shapiro-Wilk } \\
\hline Statistic & \multicolumn{1}{|c|}{$\boldsymbol{d} \boldsymbol{f}$} & \multicolumn{1}{c|}{ Sig. } \\
\hline .937 & 16 & .316 \\
.949 & 16 & .478 \\
\hline
\end{tabular}

Terlihat bahwa nilai signifikansi (Sig.) data skor pre-test kelas eksperimen adalah 0,316 sebagai pengujiannya lebih besar dari 0,05 maka Ho diterima. Hal ini berarti kelas eksperimen pre-test berasal dari populasi yang berdistribusi normal. Selanjutnya signifikansi dari kelompok kontrol pre-test memperoleh signifikansi $\quad 0,478 \quad$ sebagai pengujiannya lebih besar daripada 0,05 maka $\mathrm{H}_{\mathrm{o}}$ diterima, sehingga kelompok kontrol pre-test berasal dari populasi yang berdistribusi normal. Karena kedua kelompok berasal dari populasi yang berdistribusi normal maka dilanjutkan dengan uji homogenitas.

b) Uji Homogenitas Data Pre-Test 
Hasil uji homogenitas kelompok eksperimen dan kelompok kontrol pre-test

\begin{tabular}{|c|c|c|c|}
\hline $\begin{array}{c}\text { Levene } \\
\text { Statistic }\end{array}$ & $d f 1$ & $d f 2$ & Sig. \\
\hline .00 & & & 30 \\
\hline 1
\end{tabular}

Diperoleh hasil uji homogenitas dengan menggunakan uji Lavene's dengan signifikansi (Sig.) $\alpha=0,05$ nilai signifikansi yang diperoleh yaitu 0,972 lebih besar daripada $\alpha=0,05$ maka $\mathrm{H}_{\mathrm{O}}$ diterima, artinya data pre-test kelompok eksperimen dan kelompok kontrol mempunyai varians yang homogen. Karena kedua data pre-test tersebut memenuhi kriteria normalitas dan homogenitas maka selanjutnya dapat dilakukan uji perbedaan rerata.

c) Uji Perbedaan Rerata Data Awal (Pre-Test)

Hasil uji perbedaan rerata kelompok eksperimen dan kelompok kontrol

\begin{tabular}{|c|r|r|r|}
\multicolumn{1}{|c|}{ (pre-test) } \\
\hline $\mathrm{t}$ & \multicolumn{1}{c|}{ Df } & $\begin{array}{c}\text { Sig. }(2- \\
\text { tailed) }\end{array}$ & $\begin{array}{c}\text { Mean } \\
\text { Difference }\end{array}$ \\
\hline .459 & 30 & .650 & .62500 \\
.459 & 29.925 & .650 & .62500 \\
\hline
\end{tabular}

Dapat diamati kriteria pengujian berdasarkan taraf signifikansi $\alpha=0,05$ dapat dilihat pada data sig 2 tailed memiliki hasil sebesar 0,650. Maka hal tersebut menunjukkan bahwa hasil pengujian $\geq 0,05$ sehingga dapat disimpulkan bahwa tidak terdapat perbedaan yang signifikan antara data awal (pre-test) kecerdasan logika matematika anak usia dini antara kelas eksperimen dan kelas kontrol.

Analisis Profil (Skor Post-test) Kecerdasan Logika MatematikaAnak Usia Dini

a) Uji Normalitas Data Post-Test
Hasil uji normalitas (post-test) kelas eksperimen dan kelas kontrol

\begin{tabular}{|r|r|r|}
\hline \multicolumn{3}{|c|}{ Shapiro-Wilk } \\
\hline Statistic & \multicolumn{1}{|c|}{ Df } & \multicolumn{1}{c|}{ Sig. } \\
\hline .964 & 16 & .739 \\
.949 & 16 & .472 \\
\hline
\end{tabular}

Nilai signifikansi (Sig.) data akhir kelas eksperimen adalah 0,739 sebagai pengujiannya lebih besar daripada 0,05 maka $\mathrm{Ho}_{\mathrm{o}}$ diterima. Hal ini berarti kelas eksperimen post-test berasal dari populasi yang berdistribusi normal. Selanjutnya signifikansi dari kelompok kontrol pre-test memperoleh signifikansi $\quad 0,472 \quad$ sebagai pengujiannya lebih besar daripada 0,05 maka Ho diterima, sehingga dapat diketahui bahwa kelompok kontrol post-test berasal dari populasi yang berdistribusi normal. Karena kedua kelompok berasal dari populasi yang berdistribusi normal maka dilanjutkan dengan uji homogenitas.

b) Uji Homogenitas Data Post-Test Hasil uji homogenitas kelompok eksperimen dan kelompok kontrol post-test

Test of Homogeneity of Variances POSTEST

\begin{tabular}{|c|c|c|c|}
\hline $\begin{array}{c}\text { Levene } \\
\text { Statistic }\end{array}$ & $d f 1$ & $d f 2$ & Sig. \\
\hline .849 & 1 & 30 & .364 \\
\hline
\end{tabular}

Hasil uji homogenitas dengan menggunakan uji Lavene's dengan signifikansi (Sig.) $\alpha=0,05, \quad$ nilai signifikansi yang diperoleh yaitu 0,364 dan hasilnya lebih besar daripada $\alpha=0,05$ maka $\mathrm{Ho}_{\mathrm{o}}$ diterima, artinya data akhir kelompok eksperimen dan kelompok kontrol mempunyai varians yang homogen. Karena kedua data post-test tersebut memenuhi kriteria normalitas dan homogenitas maka selanjutnya dapat dilakukan uji perbedaan rerata.

c) Uji Perbedaan Rerata Hasil uji perbedaan rerata kelompok eksperimen dan kelompok kontrol (post-test) 


\begin{tabular}{|c|r|c|c|}
\hline$T$ & Df & $\begin{array}{c}\text { Sig. (2- } \\
\text { tailed) }\end{array}$ & $\begin{array}{c}\text { Mean } \\
\text { Difference }\end{array}$ \\
\hline 13.234 & 30 & .000 & 20.18750 \\
\hline 13.234 & 28.809 & .000 & 20.18750 \\
\hline
\end{tabular}

Dapat diamati kriteria pengujian berdasarkan taraf signifikansi $\alpha=0,05$ dapat dilihat pada data Sig (2-tailed) memiliki hasil sebesar 0,00. Maka hal tersebut menunjukkan bahwa hasil pengujian $<0,05$. Dapat disimpulkan bahwa terdapat perbedaan yang signifikan data akhir kecerdasan logika matematika anak usia dini antara kelas eksperimen dan kelas kontrol. Berdasarkan hasil analisis dan pengujian hipotesis maka terdapat perbedaan yang signifikan data akhir kecerdasan logika matematika anak usia dini yang menggunakan alat permainan edukatif busy book dan anak usia dini yang tidak menggunakan busy book.

\section{Pembahasan Hasil Penelitian}

Pada bagian ini peneliti akan membahas dan mendeskripsikan mengenai hasil penelitian yang dilakukan di lapangan. Diketahui bahwa penelitian ini bertujuan untuk mengetahui sejauh mana efektivitas dari penggunaan alat permainan edukatif busy book. Penelitian ini dilakukan pada kelas B, yang terdiri atas Kelas Gamelan sebagai kelas eksperimen dan Kelas Kecapi sebagai kelas kontrol. Pada kelas eksperimen diberikan perlakuan khusus yaitu treatmen menggunakan alat permainan edukatif busy book sedangkan kelas kontrol diberikan treatment seperti yang biasanya saat pembelajaran di sekolah berlangsung tanpa menggunakan alat permainan edukatif busy book, namun menggunakan alat permainan edukatif konvensional yang biasa dilakukan di kelas (balok dan flashcard).

Saat kelompok eksperimen diberikan treatment berupa penggunaan alat permainan edukatif busy book anak terlihat antusias dan fokus saat menyelesaikan aktivitas yang terdapat di dalam busy book. Kondisi profil akhir diperoleh bahwa pada kelompok eksperimen yang pada mulanya sebelum dilaksanakannya treatment berkriteria Berkembang baik hanya terdapat $8 \%$ anak, sedang berproses sebanyak $48 \%$ dan belum berkembang terdapat $44 \%$ anak. Namun setelah diberikan treatment pada kelompok eksperimen penggunaan alat permainan edukatif maka diperoleh $49 \%$ anak mulai berkembang baik, $45 \%$ anak sedang berproses dan belum berkembang sebanyak $5 \%$ anak

Data yang dihasilkan pada kelompok eksperimen dan kelompok kontrol, jika dilihat dari rata-rata uji t pada kelompok eksperimen dan kelompok kontrol saat post-test, diperoleh bahwa kriteria pengujian memiliki hasil sebesar 0,00. Maka hal tersebut menunjukkan bahwa hasil pengujian $<0,05$. Dapat disimpulkan bahwa terdapat perbedaan yang signifikan data akhir kecerdasan logika matematika anak usia dini antara kelas eksperimen dan kelas kontrol. Berdasarkan hasil analisis dan pengujian hipotesis maka terdapat perbedaan yang signifikan data akhir kecerdasan logika matematika anak usia dini yang menggunakan alat permainan edukatif busy book dan anak usia dini yang tidak menggunakan busy book. Terlihat bawa perbedaan yang cukup jauh dari hasil uji t pada saat post-test kedua kelompok eksperimen dan kelompok kontrol, sehingga dapat ditarik kesimpulannya alat permainan edukatif busy book memiliki efektivitas dalam menstimulasi kecerdasan logika matematika anak usia dini

\section{KESIMPULAN}

Berdasarkan hasil penelitian dan hasil pengolahan data yang dilakukan maka diperoleh kesimpulan sebagai berikut: 
1) Tidak terdapat perbedaan pada profil kecerdasan logika matematika anak usia dini yang signifikan sebelum menerapkan penggunaan alat permainan edukatif busy book di kelas eksperimen dan alat permainan edukatif konvensional di kelas kontrol

2) Terdapat perbedaan pada profil kecerdasan logika matematika anak usia dini yang signifikan setelah menerapkan penggunaan alat permainan edukatif busy book di kelas eksperimen dan alat permainan

\section{DAFTAR PUSTAKA}

Annisa, M. (2016). Pengaruh Pembelajaran Menggunakan Alat Permainan Edukatif Busy Book Terhadap Kecerdasan VisualSpasial Anak (Doctoral Dissertation, Universitas Pendidikan Indonesia).

Caturiyati, K. H., \& Himmawati, P. L. (2007). UpayaUpaya Mengembangkan

Kecerdasan

Logical/Mathematical

$$
\text { Pada }
$$

Pembelajaran Terpadu Model Webbed Berbasis Kecerdasan Jamak Di Tkit Salman Al Farisi II Yogyakarta. In Prosiding Seminar Nasional Matematika Dan Pendidikan Matematika, Pipm.

Gardner, H. (1983). Frames Of Mind: The Theory of

\section{Multiple}

Intelligences. New York: Basic Books.

Hainstock, E. G., \& Lumley, B. (1999). Metode pengajaran montessori untuk anak pra- sekolah. Pustaka Delapratasa

Hidayati, K. (2015). Hubungan Antara Tingkat Pendidikan Ibu Dan Kecerdasan Indriati, N. U. D. (2016). Instrumen Tes Kecerdasan Logika-Matematika Untuk Anak Usia Dini. Jurnal Pendidikan Usia Dini, 10(1), 171-184.

http://www.earlychildhoodnews.com/ea edukatif konvensional di kelas kontrol

3) Terdapat perbedaan peningkatan kecerdasan logika matematika anak usia dini sebelum dan setelah penggunaan alat permainan edukatif busy book di kelas eksperimen dan konvensional di kelas kontrol yang signifikan dari penggunaan alat permainan edukatif busy book terhadap kecerdasan logika matematika anak usia dini, sehingga terdapat efektivitas dalam penggunaan alat permainan edukatif busy book terhadap kecerdasan logika matematika anak usia dini.

rlychildhood/article_print.aspx?A $\underline{\text { rticleId }=251 \text { diakses pada } 10}$ Agustus 2019, Pukul 19.30

Indriani, N. U. D. (2016). Instrumen Tes Kecerdasan Logika-Matematika Untuk Anak Usia Dini. Jurnal Pendidikan Usia Dini, 10(1), 171184.

Lazear, David. (2000). Pathways Of Learning: Teaching Students And Parents About Multiple Intelligences. Tucson, Arizona: Zephyr Press, 7-12

Merrill Bruner, J. S. (1996). The culture of education. Harvard University Press.

Mufarizuddin, M. (2017). Peningkatan Kecerdasaan Logika Matematika Anak Melalui Bermain Kartu Angka Kelompok B Di Tk Pembina Bangkinang Kota. Jurnal Obsesi: Jurnal Pendidikan Anak Usia Dini, 1(1), 62-71.

Musfiroh, T. (2004). Multiple Intelligences. PAUD lemlitUNY, PBSI FBS-UNY. 
(2006). Salkind (2009). Exploring Research.

Rahma, A. (2014). Efektivitas Penggunaan Alat Permainan Edukatif (APE) Untuk Meningkatkan Perkembangan Kognitif siswa: Kuasi Eksperimen Pada Kegiatan Pembelajaran Konsep Bilangan, Lambang Bilangan Dan Huruf di Kelas B Tk Pembina Kab. Subang (Doctoral Dissertation, Universitas Pendidikan Indonesia).

Rozi, N. (2012). Peningkatan Kecerdasan Logika Matematika Anak Melalui Permainan Berhitung Menggunakan Papan Telur. Tk Aisyiyah 7 Duri. Jurnal Ilmiah Pesona Paud, 1(1).

Salkind, N. J.(2009). Exploring research.

Silmi, A. N., Windayana, H., \& Sutini, A. I. (2015). Mengembangkan Kemampuan Kecerdasan Logika Matematika Anak Usia Dini Melalui Permainan Flashcard. Jurnal Pgpaud Kampus Cibiru, 3(3).

Simister, C. J. (2007). How to teach thinking and learning skills: A practical programme for the whole school. Sage.

Smith, M. K. (2002). Howard Gardner and multiple intelligences. The encyclopedia of informal education, 15, 2012.

Sujiono, Y. N. (2009). Konsep dasar pendidikan anak usia dini.

Sujiono, Y. N., \& Sujiono, B. (2010). Bermain kreatif berbasis kecerdasan jamak. Jakarta: Indeks, 76.

Suryani, N. A., \& Haryono, M. (2018). Improvement of The Logical Intelligence Through
Media Kolak (Collage

Numbers) Based On Local

Wisdom On Early Childhood.

Jurnal Obsesi: Jurnal

Pendidikan Anak Usia Dini, 2(2), 253-258.

Susyanti, N., Nina, K., \& Rita, S. (2013).

Mengembang

kan Kecerdasan Logika Matematika Pada Anak Usia Dini Melalui Metode Jarimagic (Doctoral Dissertation, Fakultas Keguruan Dan Ilmu Pendidikan Universitas Bengkulu).

Setyosari, Punaji. 2010. Metode Penelitian dan Pengembangan. Jakarta. Kencana Prenada

Umar, Husein. 2008. Desain Penelitian MSDM dan Perilaku karyawan: Paradigma Positivistik dan Berbasis Pemecahan Masalah. PT Rajagrafindo Persada

Wulani, S. S. (2011). Pengaruh Permainan Tradisional Congklak Terhadap Kecerdasan Logika Matematika Anak Di Raudhatul Athfal Aisyiyah Rejosari Tahun Pelajaran 2010/2011(Doctoral

Dissertation, Universitas Muhammadiyah Surakarta).

Yuliani, N. S. (2009). Konsep Dasar Pendidikan Anak Usia Dini. Jakarta: Indeks.

Zubaidah, B., Dharmayana, I. W., \& Delrefi, D. (2012). Meningkatkan Kecerdasan Logika Matematika Melalui Permainan Ular Tangga Pada Kelompok B1 Tk Negeri 
Pembina Padang Ulak Tanding Kabupaten Rejang

Lebong (Doctoral Dissertation, Universitas Bengkulu).

Zukhairina, Z. (2018). Membangun Kecerdasan Logika Matematika Anak Usia Dini (Aud) Di Sentra Balok Dengan penggunaan Term, Fact, And Principle (TFP) di PAUD Sekolah Al-Falah Ciracas Jakarta Timur. JISEC (Journal Of Islamic Studies For Early Childhood), 1(1), 95-121.

Suyadi, M. P. I. (2010). Psikologi Belajar PAUD. Yogyakarta: Pedagogia.

Suyanto, M. (2003). Multimedia alat untuk meningkatkan keunggulan bersaing. Penerbit Andi.
Anita Yus, 2011 Model Pendidikan Anak Usia Dini. Jakarta: Kencana.

Agustin,Mubiar.2008.Mengenalida Mengembangkan Potensi Kecerdasan JamakAnakUsiaTaman Kanakkanak/

RaudhatulAthfal.Bandung: Rizqipress.

Nur, Firly. (2018)."Proses Berpikir Siswa SMP Dengan Kecerdasan Linguistik Dan Kecerdasan Logis-Matematis Dalam Menyelesaikan Soal Cerita." Jurnal Ilmiah Pendidikan Matematika7, no. 3.

Fadlillah, M. (2014). Implementasi Kurikulum 2013 dalam pembelajaran SD/MI, SMP/MTS, dan SMA/MA. Yogyakarta: Ar-Ruzz Media 
